\title{
Constraints in the application of the Branched and Isoprenoid Tetraether index as a terrestrial input proxy
}

\author{
Susanne Fietz, ${ }^{1}$ Alfredo Martínez-Garcia, ${ }^{2}$ Carme Huguet, ${ }^{1}$ Gemma Rueda, ${ }^{1}$ \\ and Antoni Rosell-Melé ${ }^{1,3}$ \\ Received 17 February 2011; revised 3 August 2011; accepted 12 August 2011; published 29 October 2011.
}

[1] Determination of the relative inputs of aquatic autochthonous and terrestrial allochthonous organic matter into marine and lacustrine environments is essential to understanding the global carbon budget. A variety of proxies are used for this purpose, including the Branched and Isoprenoid Tetraether (BIT) index. This is calculated from the concentrations of branched glycerol dialkyl glycerol tetraethers (GDGTs), derived from unidentified terrestrial bacteria, and crenarchaeol, a marker for aquatic mesophile Thaumarchaeota (Crenarchaeota group I). As the index is a ratio, its value depends on both the crenarchaeol aquatic in situ production and the soil-derived branched GDGT input. Therefore, the BIT index reflects not only changes in the input of terrestrial or soil organic matter but also relative variations in aquatic Thaumarchaeota abundance in the water column. In fact, we show that in oceanic and lacustrine settings, the BIT index can be dominated by the aquatic end-member of the ratio. Consequently, the BIT index by itself can be an unreliable proxy to compare the input of terrestrial matter between sites and over time, and we propose that the quantification of branched GDGT fluxes or concentrations may instead be a better indicator of soil terrestrial inputs.

Citation: Fietz, S., A. Martínez-Garcia, C. Huguet, G. Rueda, and A. Rosell-Melé (2011), Constraints in the application of the Branched and Isoprenoid Tetraether index as a terrestrial input proxy, J. Geophys. Res., 116, C10032, doi:10.1029/2011JC007062.

\section{Introduction}

[2] The fate of terrestrial organic matter in marine and lacustrine sediments and its influence on sediment carbon burial and preservation need to be established for a better understanding of the global carbon cycle. Different proxies are currently used to trace the origin of organic matter in sediments, e.g., carbon to nitrogen $(\mathrm{C}: \mathrm{N})$ ratio, organic carbon isotopic composition $\left(\delta^{13} \mathrm{C}_{\mathrm{org}}\right)$, n-alkane and lignin phenol abundances [e.g., Gordon and Goñi, 2003; Weijers et al., 2009a]. However, as they are influenced by more than one parameter, a multiproxy approach is generally recommended [e.g., Hedges and Oades, 1997; Meyers, 1997; Pancost and Boot, 2004; Birks and Birks, 2006]. One of the most novel proxies to trace terrestrial organic carbon inputs was introduced by Hopmans et al. [2004] as the Branched and Isoprenoid Tetraether (BIT) index, based on the measurement of glycerol dialkyl glycerol tetraethers (GDGTs).

[3] Branched GDGTs were first identified in soils and peat bogs and present branched alkyl chains. By analogy with the

\footnotetext{
${ }^{1}$ Institut de Ciència i Tecnologia Ambientals, Universitat Autònoma de Barcelona, Barcelona, Spain.

${ }^{2}$ Geologisches Institut, ETH Zurich, Zurich, Switzerland.

${ }^{3}$ Also at Institució Catalana de Recerca i Estudis Avançats, Barcelona, Spain.

Copyright 2011 by the American Geophysical Union. 0148-0227/11/2011JC007062
}

structures of bacterial lipids, their source organisms were postulated to be soil bacteria, but so far their exact provenance has not been conclusively ascertained [Weijers et al., 2006a, 2009b]. Acidobacteria were proposed as likely candidates [Weijers et al., 2009b] and recently a branched GDGT was indeed identified in two acidobacteria cultures [Sinninghe Damsté et al., 2011]. Marine bacteria do not seem to synthesize branched GDGTs because those lipids have not been detected or are present only in low abundances in open ocean samples [Hopmans et al., 2004]. Recently, however, in situ production of branched GDGTs in marine and lacustrine sediments has been suggested since core branched GDGTs were found at sites with low direct runoff or fluvial inputs, and because their distributions did not match those in nearby soils [Peterse et al., 2009; Sinninghe Damsté et al., 2009; Tierney et al., 2010].

[4] Isoprenoid GDGTs instead are derived from Archaea, and crenarchaeol has been proposed as a marker for pelagic Thaumarchaeota (mesophile Archaea, formerly Crenarchaeota group I [Brochier-Armanet et al., 2008; Sinninghe Damsté et al., 2002]). Low abundances of crenarchaeol have also been found in isolates and samples from terrestrial environments such as soils and peats [Leininger et al., 2006; Weijers et al., 2006b; Walsh et al., 2008], as well as in hot springs [Pearson et al., 2004; de la Torre et al., 2008; Pitcher et al., 2009], and rivers [Herfort et al., 2006; Kim et al., 2007], indicating that the producing organisms are more widespread than initially thought. 
[5] The BIT index describes the ratio between the branched and the isoprenoid tetraether crenarchaeol [Hopmans et al., 2004]. It was proposed as a proxy for the relative input of soil organic matter to coastal marine sediments [Hopmans et al., 2004]. Indeed, BIT values have been shown to track a plume from the mouth of the Congo River into the open ocean [Hopmans et al., 2004], the fluvial input of terrestrial matter into the North Sea [Hopmans et al., 2004; Herfort et al., 2006], as well as storm-flood events in a river dominated continental margin [Kim et al., 2007, 2009]. The BIT is also increasingly used as a proxy to estimate modern and trace past changes in "terrestrial organic matter (or soil organic matter) input" [e.g., Ménot et al., 2006; Sluijs et al., 2006; Huguet et al., 2007; Donders et al., 2009; Weijers et al., 2009a].

[6] However, several constraints in the use of the BIT have been reported. These include concerns about the interlaboratory comparability of the BIT as it is very sensitive to analytical instrumental conditions and therefore their relative responses vary between laboratories [Escala et al., 2009; Schouten et al., 2009]. It has also been argued that the BIT is a specific proxy for soil input rather than for bulk terrestrial matter, and is thus sensitive to the lack of well developed soils in the potential source regions [Walsh et al., 2008; Belicka and Harvey, 2009]. Weijers et al. [2009a] attempted to quantify the relative soil organic carbon input in a downcore record from the Congo Fan, but as the authors pointed out, this required assuming similar and constant concentrations of the terrestrial and marine biomarkers versus bulk terrestrial and marine organic carbon, respectively. Furthermore, Huguet et al. [2008] found that the BIT index was affected by diagenesis, as degradation rates of crenarchaeol were twofold higher than those of soil-derived branched GDGTs. Variability in terrestrial organic matter sources, transport, and degradation was also suggested to explain a weak correlation found between BIT and lignin phenol, while the BIT was correlated to bulk sedimentary organic matter proxies [Smith et al., 2010]. Herfort et al. [2006], Walsh et al. [2008], and Belicka and Harvey [2009] furthermore have reported low BIT indices at sites with high terrestrial organic carbon inputs and pointed out that apart from variations in the sources of the terrestrial material, large crenarchaeol concentration changes may also drive the BIT changes. Here we show that indeed the BIT is often driven by the variability of crenarchaeol concentration rather than that of branched GDGTs.

\section{Methods}

\subsection{Core Locations}

\subsubsection{Lake Baikal Record}

[7] Lake Baikal is located in Siberia, Russia, in one of the most continental regions of the world. It is the deepest and one of the largest freshwater lakes of the world. The lake surface freezes for 4-6 months each year, but the water column remains oxygenated throughout [Schmid et al., 2008]. Diatoms are the dominant phytoplankton group, occasionally forming extensive blooms [Kozhova and Izmest'eva, 1998], and Lake Baikal sediments consist of alternating layers of organic, diatom-rich, and inorganic diatom-poor sediments indicative of changing productivity linked to climate (see Mackay [2007] for a review). The two core intervals used in this study cover a time span from $\sim 107$ to $\sim 130$ kyr B.P. (last interglacial period and transitions) and approximately the past $50 \mathrm{kyr}$ (part of last glacial period, including interstadial MIS3, and Holocene [Escala, 2009]). Sediment core CON01-603-3 was retrieved from the North Basin $\left(53^{\circ} 57^{\prime} \mathrm{N}, 108^{\circ} 55^{\prime} \mathrm{E}\right)$ at $386 \mathrm{~m}$ water depth. The overall age model was based on magnetostratigraphic correlation [Démory et al., 2005], while the determination of the last interglacial section was based on the core lithology and correlation of high-resolution pollen and diatom records [Fietz et al., 2007].

\subsubsection{Southern Ocean Record}

[8] Core PS2489-2 $\left(42^{\circ} 52^{\prime} \mathrm{S}, 8^{\circ} 58^{\prime} \mathrm{E}\right)$ was recovered from the Atlantic Southern Ocean at $3794 \mathrm{~m}$ water depth. This site is located in the present-day subantarctic zone and is particularly influential for the marine carbon reservoir through changes in westerly winds position and iron fertilization of marine biota [Martínez-Garcia et al., 2009, 2011]. It is characterized by relatively low phytoplankton export production during interglacial periods and high export production during glacial stages essentially stimulated by atmospheric supply of iron [Martinez-Garcia et al., 2009, 2011]. The record studied covers from the mid-Pleistocene to the Holocene, encompassing several glacial and interglacial cycles (MIS 1 to MIS 12, 500 kyr B.P.). The age model used in this study is published by Martinez-Garcia et al. [2009].

\subsubsection{Fram Strait Record}

[9] Core MSM05/05-712-1 was retrieved from the eastern Fram Strait at $1490 \mathrm{~m}$ water depth $\left(7^{\circ} 54^{\prime} \mathrm{N}, 6^{\circ} 46^{\prime} \mathrm{E}\right)$. This site is strategically situated in the path of Atlantic water inflow to the Arctic Ocean [Spielhagen et al., 2011]. Most of the recent organic matter in this region is autochthonous with terrestrial organic matter supply being likely a result of long-range sea ice transport from the Svalbard archipelago and from the northern Barents Sea [Hebbeln, 2000]. The core spans approximately the last 2000 years [Spielhagen et al., 2011].

\subsubsection{NE Atlantic Record}

[10] Core MD01-2461 was collected from the Northeast (NE) Atlantic $\left(51^{\circ} 45^{\prime} \mathrm{N}, 12^{\circ} 55^{\prime} \mathrm{W}\right)$ at $1153 \mathrm{~m}$ water depth. The site is located in the northwestern flank of the Porcupine Seabight, close to a principal outlet glacier draining the British Ice Sheet and also received ice rafted debris derived from other North Atlantic margins [Peck et al., 2006]. The analyzed section spans from 24.5 to $14.5 \mathrm{kyr}$ B.P., across the last glacial maximum and Heinrich events 1 and 2 [Peck et al., 2006].

\subsubsection{Alboran Sea Record}

[11] Core ODP-977A was retrieved from the eastern subbasin of the Alboran Sea $\left(36^{\circ} 02^{\prime} \mathrm{N}, 1^{\circ} 57^{\prime} \mathrm{W}\right)$, in a transitional area between the Atlantic and the Mediterranean. The region has a complex water column structure with deep Mediterranean and surface Atlantic water masses. The analyzed section spans 145-245 kyr B.P. [Huguet et al., 2011] and comprises characteristic sequences of rapid warming and cooling events [Martrat et al., 2004].

\subsection{Sample Processing and Analyses}

\subsubsection{Extraction}

[12] One to $5 \mathrm{~g}$ homogenized freeze-dried sediment from Lake Baikal, Southern Ocean, NE Atlantic, and Fram 
Strait were extracted by microwave using a mixture of dichloromethane/methanol $(3 / 1 \mathrm{vol} / \mathrm{vol})$. The temperature of the vessel containing the sample was increased to $70^{\circ} \mathrm{C}$ over $5 \mathrm{~min}$, held at $70^{\circ} \mathrm{C}$ for $5 \mathrm{~min}$ and then decreased to $30^{\circ} \mathrm{C}$. One to $2 \mathrm{~g}$ freeze-dried sediment from the Alboran Sea were extracted using an Accelerated Solvent Extractor 200 (ASE 200, DIONEX) with a mixture of dichloromethane/ methanol $(9 / 1 \mathrm{vol} / \mathrm{vol})$ at $100^{\circ} \mathrm{C}$ and $7.610^{6} \mathrm{~Pa}$. Extracts were filtered through a Pasteur pipette filled with sodium sulfate to remove water and then taken to dryness by centrifugal vacuum concentration (miVac, Genevac) or under gentle nitrogen stream.

\subsubsection{Fractionation}

[13] Lake Baikal, NE Atlantic and Alboran Sea extracts were manually fractionated with activated alumina in a Pasteur pipette using mixtures of hexane/dichloromethane (9/1 vol/vol) and dichloromethane/methanol (1/1 vol/vol) as eluents [Sinninghe Damsté et al., 2002; Escala et al., 2009]. Southern Ocean extracts were analyzed without further fractionation. Fram Strait extracts were redissolved in $100 \mu \mathrm{L}$ hexane/dichloromethane $(50 / 50 \mathrm{vol} / \mathrm{vol})$ prior to manual injection in a Thermo Surveyor HPLC system equipped with a Lichrosphere Silicon dioxide column $(4.6 \times 250 \mathrm{~mm}, 5 \mu \mathrm{m}$; Teknokroma) and a stainless steel inline filter $(2 \mu \mathrm{m}$ pore size). Compound class fractionation was achieved running n-hexane (0-2.7 $\mathrm{min})$, dichloromethane (2.7-5.7 $\mathrm{min})$, acetone (5.7-9.2 $\mathrm{min})$ and $\mathrm{n}$-hexane $(9.2-13.5 \mathrm{~min})$ with a $2 \mathrm{~mL} \mathrm{~min}^{-1}$ flow.

\subsubsection{Instrumental Analysis}

[14] The dry polar fractions were redissolved in hexane/ n-propanol $(99 / 1 \mathrm{vol} / \mathrm{vol})$ and filtered through $0.50 \mu \mathrm{m}$ PTFE filters (Advantec). A Dionex P680 HPLC system coupled to a Thermo Finnigan TSQ Quantum Discovery Max quadrupole mass spectrometer with an APCI interface was used. The target compounds were separated with a Tracer Excel CN column $(0.4 \times 20 \mathrm{~cm}, 3 \mu \mathrm{m}$; Teknokroma $)$ equipped with a precolumn filter and a guard column. The solvent program was modified from Schouten et al. [2007] and Escala et al. [2007]. Samples were eluted with hexane/n-propanol at $0.6 \mathrm{~mL} \mathrm{~min} \mathrm{~m}^{-1}$. The amount of $\mathrm{n}$-propanol was held at $1.5 \%$ for $4 \mathrm{~min}$, increased gradually to $5.0 \%$ during $11 \mathrm{~min}$, then increased to $10 \%$ during $1 \mathrm{~min}$ and held at $10 \%$ for $4 \mathrm{~min}$, then decreased to $1.5 \%$ during $1 \mathrm{~min}$ and held at $1.5 \%$ for $9 \mathrm{~min}$ until the end of the run. The parameters of the APCI were set as follows to generate positive ion spectra: corona discharge $3 \mu \mathrm{A}$, vaporizer temperature $400^{\circ} \mathrm{C}$, sheath gas pressure 49 mTorr, auxiliary gas $\left(\mathrm{N}_{2}\right)$ pressure 5 mTorr and capillary temperature $200^{\circ} \mathrm{C}$. GDGTs were monitored in selected ion monitoring (SIM) mode at mass-to-charge ratio $(\mathrm{m} / \mathrm{z}) 1292$ (crenarchaeol), 1022 (brGDGT I), 1036 (brGDGT II), and 1050 (brGDGT III). The synthetic tetraether lipid GR was used as external standard. Compound GR has a $m / z$ of 1208, a structure typical of neutral archaeal membrane lipids and presumably does not occur in the environment [Réthoré et al., 2007; Escala, 2009]. It is characterized by a hemicyclic lipid core composed of two phytanyl chains and a 31-atom-long bridging chain containing a cyclopentane ring linked together by two glycerol moieties to which they are attached via ether bonds; it furthermore has two neutral hydroxyl groups [Réthoré et al., 2007]. The HPLC-MS system was checked for $\mathrm{TEX}_{86}$ and BIT index accuracy with a standard sediment sample before and between sample sets [Escala, 2009]. External curves were measured before each sample series. The reproducibility of the quantification is estimated to be $\pm 10 \%$. The BIT index was calculated as

$$
\text { BIT }=\frac{[\text { brGDGT I }+ \text { brGDGT II }+ \text { brGDGTIII }]}{[\text { crenarchaeol }+ \text { brGDGT I }+ \text { brGDGT II }+ \text { brGDGT III }]}
$$

(codes correspond to structures shown by, e.g., Hopmans et al. [2004]).

\section{Results and Discussion}

[15] Crenarchaeol and branched GDGT concentrations in the sediment are both influenced by their respective production, transport and deposition processes. All those factors depend on the environmental conditions of any investigated site. Hence, the BIT index variability can be due to a wide range of environmental conditions. This considerably hampers the interpretation of the relative terrestrial organic matter input over time or when comparing sites. Here we first compare average BIT indices between several sites and then discuss what affects the BIT index variability over time in Lake Baikal and the site from the Southern Ocean.

\subsection{Comparison of BIT Indices Between Sites}

[16] Low BIT values do not necessarily correspond to sites with the lowest concentrations of branched GDGTs. The lowest BIT values are measured in samples from the Alboran Sea, where indeed the concentration of branched GDGTs is relatively low, but equally low BIT values are found in the Fram Strait (Figure 1a), even though the branched GDGT abundances are 1 order of magnitude higher (Figure 1b). The low BIT at the Fram Strait is due to the relatively high crenarchaeol abundances (Figure 1c). In the NE Atlantic and Southern Ocean records we also observe higher median BIT values but lower median branched GDGT concentrations, which is due to the greater difference in the crenarchaeol concentration (Figures 1a-1c).

[17] It is obvious then, from the site comparison, that variations in crenarchaeol concentrations can determine the BIT value, rather than branched GDGTs concentration changes. This is in agreement with previous work that reported low BIT values in fjords and coastal areas with high terrestrial organic carbon inputs [Herfort et al., 2006; Huguet et al., 2007; Walsh et al., 2008; Belicka and Harvey, 2009]. Furthermore, in various African lakes, the BIT index was significantly correlated with the crenarchaeol concentration but not with branched GDGTs, again indicating the greater importance of the archaeal aquatic end-member on the BIT index comparing various sites [Tierney et al., 2010].

\subsection{BIT Index Downcore Variability}

[18] In the record from the subantarctic Southern Ocean the BIT index is always high during the interglacial periods (Figure 2a), which are however characterized by very low inputs of branched GDGTs (Figure 2b). The higher BIT results from the much more pronounced decrease of crenarchaeol concentrations during the unproductive interglacial 

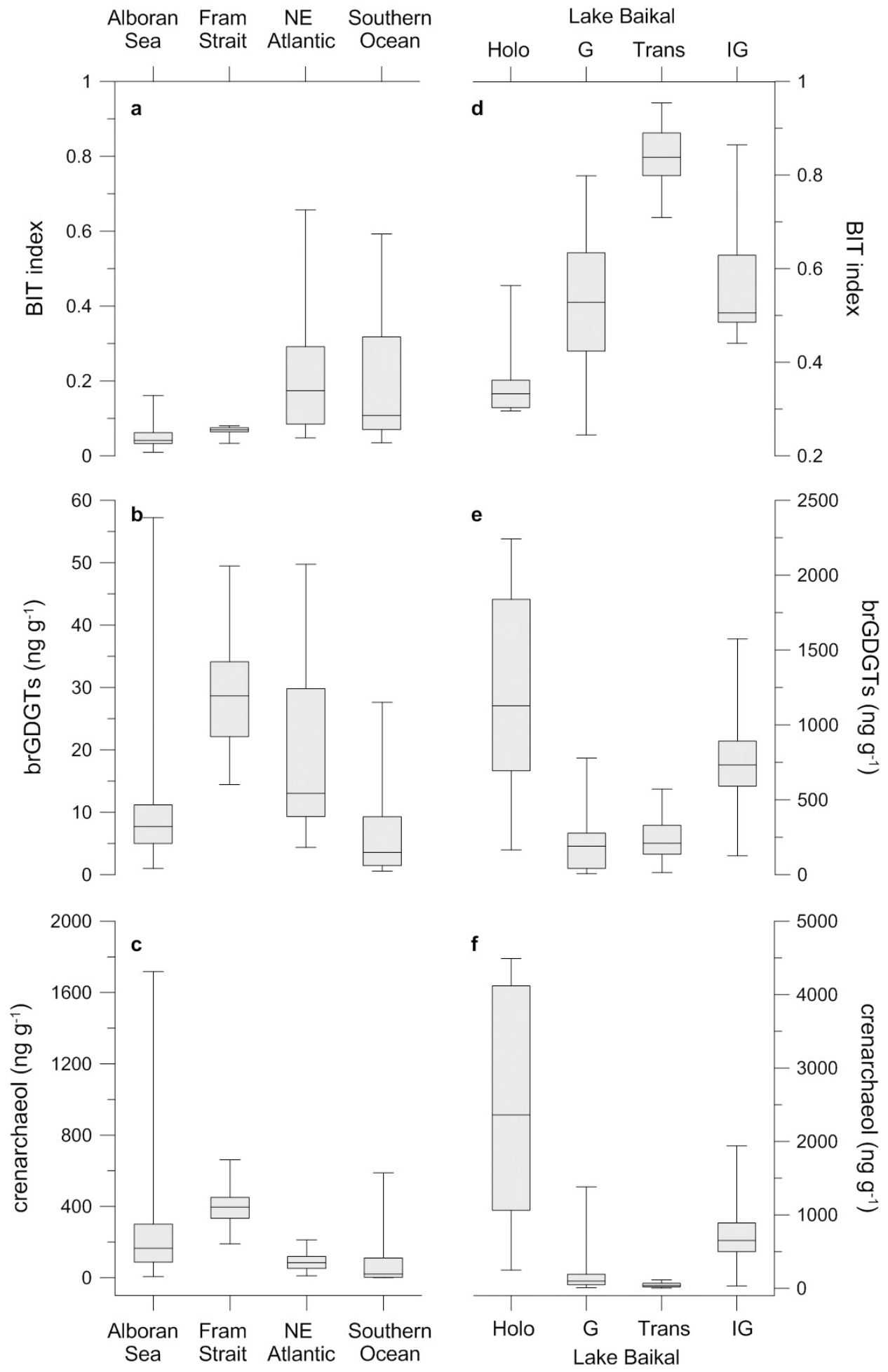

Figure 1. Branched and Isoprenoid Tetraether (BIT) index values and concentrations of crenarchaeol (ng $\mathrm{g}^{-1}$ ) and branched glycerol dialkyl glycerol tetraethers (GDGTs) $\left(\mathrm{ng} \mathrm{g}^{-1}\right)$ in (a-c) marine records and in (d-f) Lake Baikal over various time spans. Time spans for the Baikal records are shown in Figures 3 and 4; briefly, they are Holocene (Holo), 0-12 kyr B.P.; last glacial (G), 12-55 kyr B.P.; transitions (trans), $\sim 96-113$ and $\sim 127-139 \mathrm{kyr}$ B.P.; and last interglacial (IG), $\sim 113-127 \mathrm{kyr}$ B.P. Box-whisker plots indicate medians (bar), $75 \%-25 \%$ percentiles (boxes), and minima and maxima (vertical bars). 


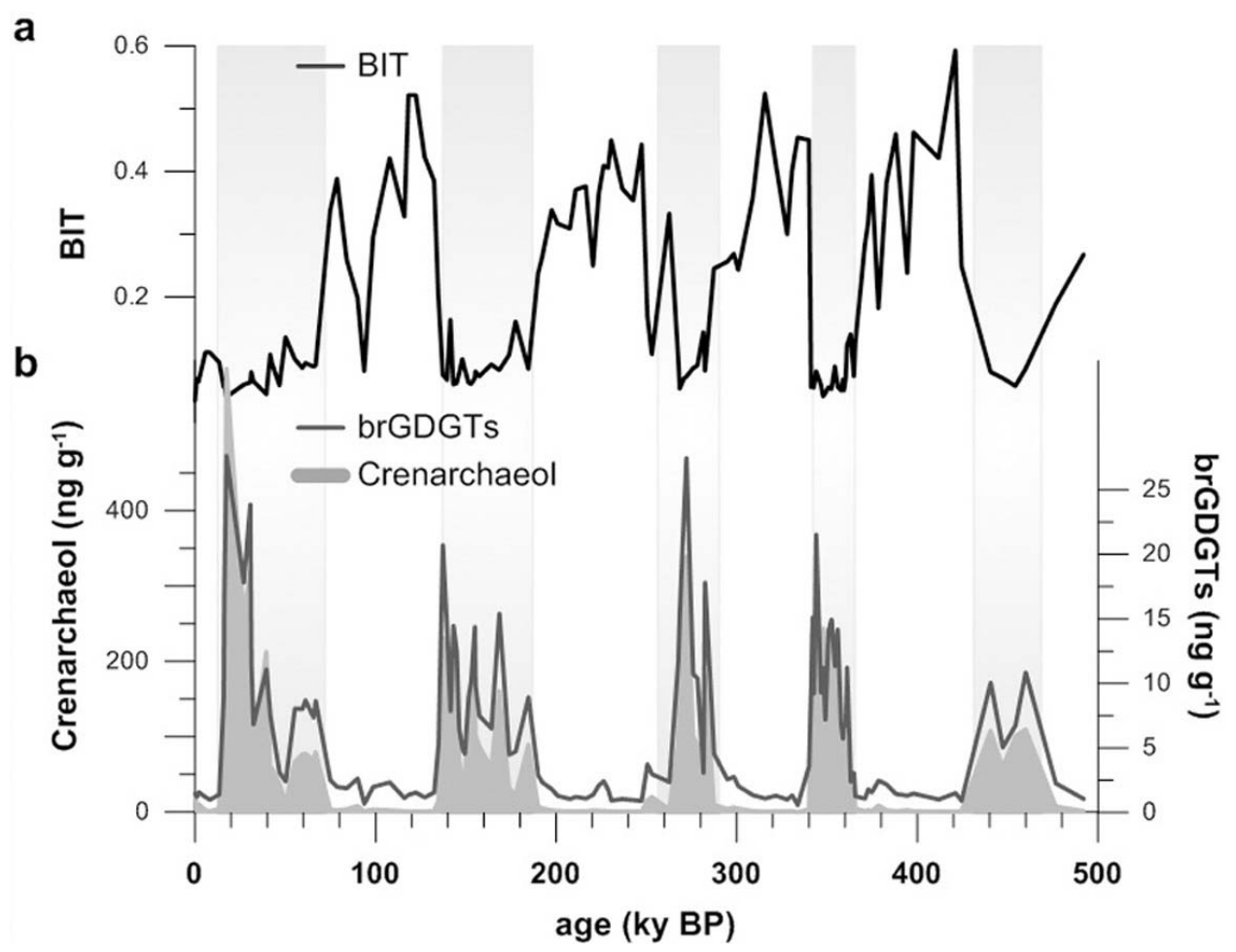

Figure 2. Subantarctic Southern Ocean record: (a) BIT index and (b) branched GDGTs and crenarchaeol. Shaded areas highlight approximately the productive glacial periods.

periods (Figure 2b). The low input of terrestrial material during interglacial periods is supported by the analysis of ${ }^{230}$ Th-normalized fluxes, mass accumulation rates and concentrations of several inorganic $\left(\mathrm{Fe}, \mathrm{Al}, \mathrm{Ti}\right.$, and $\left.{ }^{232} \mathrm{Th}\right)$ and organic tracers (long-chain odd-carbon-numbered n-alkanes) of lithogenic material [Martinez-Garcia et al., 2009, 2011]. All these tracers show the same evolution over the glacialinterglacial cycles than the branched GDGTs, and the opposite than the BIT index, i.e., high fluxes/concentrations of terrigeneous material during glacial stages and low fluxes/ concentrations during the interglacial periods.

[19] In Lake Baikal, the BIT index should be primarily affected by the input of branched GDGTs since the input of terrestrial organic matter should be much higher than in the open ocean systems. The sources of this terrestrial TOC are presumably humic substances delivered by the inflowing water from the surrounding land [Heim et al., 2005]. However, in Lake Baikal, the median BIT index for the Holocene is the lowest compared to the other periods (Figure 1d), while the branched GDGT concentrations are the highest (Figure 1e). This is due to the much more pronounced differences in crenarchaeol (Figure 1f). In fact the BIT index steadily diminishes since the last glacial toward the present (Figure 3a), while the branched GDGTs vary strongly over time (Figure 3b) [Escala, 2009]. The BIT is highest during the transitional periods at the onset and termination of the last interglacial (Figure 1a), although again, this is not due to high branched GDGT but low crenarchaeol concentrations (Figures 1e and 1f). During the last Interglacial, the BIT index decreases strongly compared to the transitional periods (Figure 4a), while the branched GDGT concentration increases (Figure 4b). Higher terrestrial input during the interglacial, contrasting with the low BIT index, was also previously suggested based on higher TOC\% and C:N values [Fietz et al., 2007]. Crenarchaeol, in contrast, shows much stronger variability (Figure $4 b$ ) explaining the strong changes in the BIT index (Figure 4a).

[20] In both the Southern Ocean and Lake Baikal, degradation might partly explain the higher BIT values during the less productive periods (interglacials for the Southern Ocean and glacials for Lake Baikal), since prolonged exposure to oxic conditions may selectively degrade crenarchaeol and artificially raise BIT values [Huguet et al., 2008]. However, the BIT is not only negatively correlated to the branched GDGT concentrations (Figures 5a and 5d) but also to other potential terrestrial input proxies (Figures $5 \mathrm{~b}$ and 5e). The branched GDGT concentrations, in contrast, show positive correlations with those other terrestrial input proxies (Figures 5c and 5f), which is in agreement with previous observations [Herfort et al., 2006; Huguet et al., 2007; Walsh et al., 2008; Weijers et al., 2009a]. One possibility to explain the parallel, stronger increase in crenarchaeol, and consequent low BIT, is the fertilization effect of terrestrial input on phytoplankton production which, in turn, triggered an increase in archaeal abundance [Fietz et al., 2011]. The $\mathrm{n}$-alkanes and ${ }^{232} \mathrm{Th}$ records indeed indicated an increase in glacial dust (and iron) deposition over the Southern Ocean, which stimulated marine export production during glacial stages [Martínez-Garcia et al., 2009, 2011]. The close coupling between crenarchaeol, phytoplankton productivity and dust can be explained, for example, if aquatic Thaumarchaeota are hetero- [e.g., Ouverney and Fuhrman, 2000] 


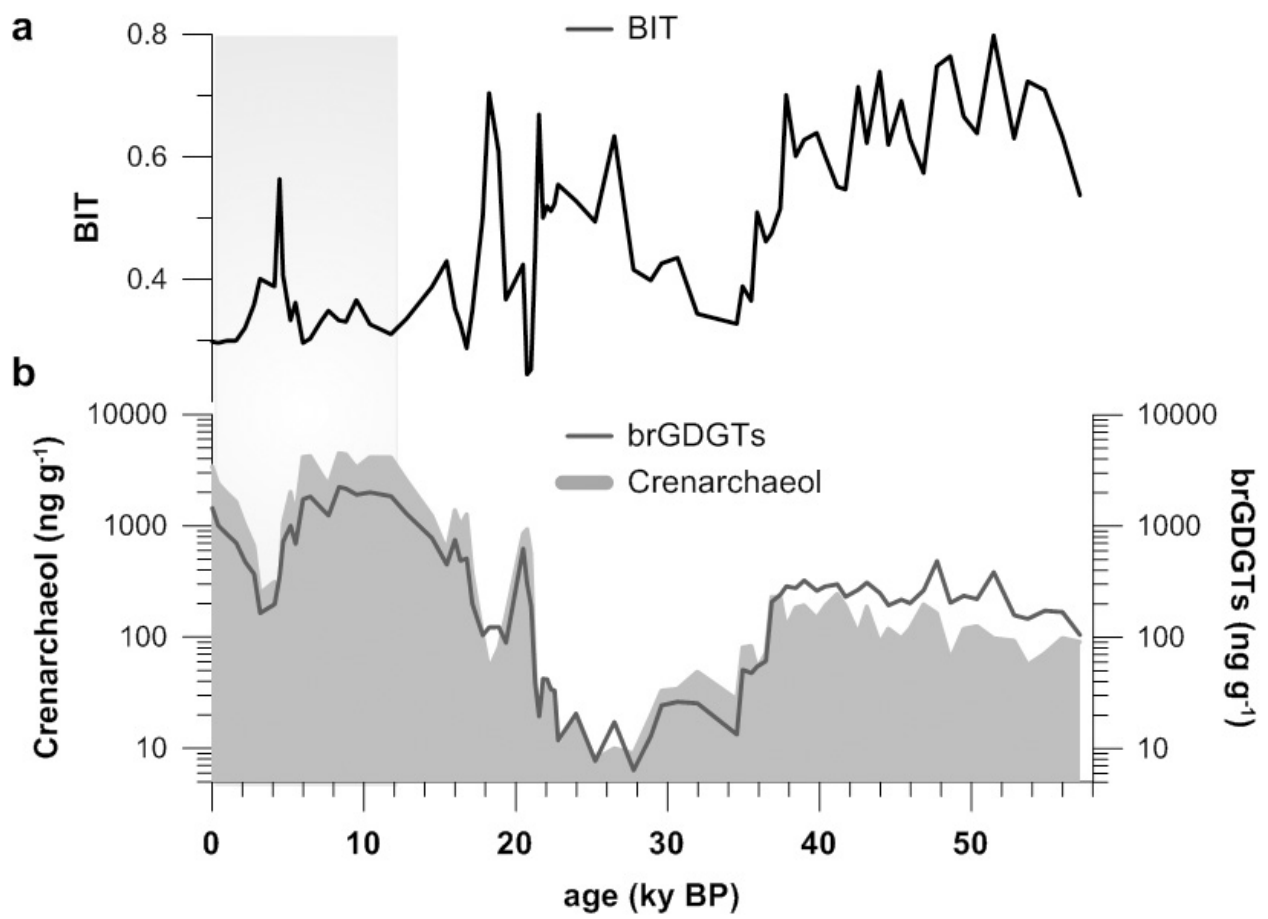

Figure 3. Lake Baikal Holocene and last glacial record [cf. Escala, 2009]: (a) BIT index and (b) branched GDGTs and crenarchaeol. The shaded area highlights approximately the Holocene period.

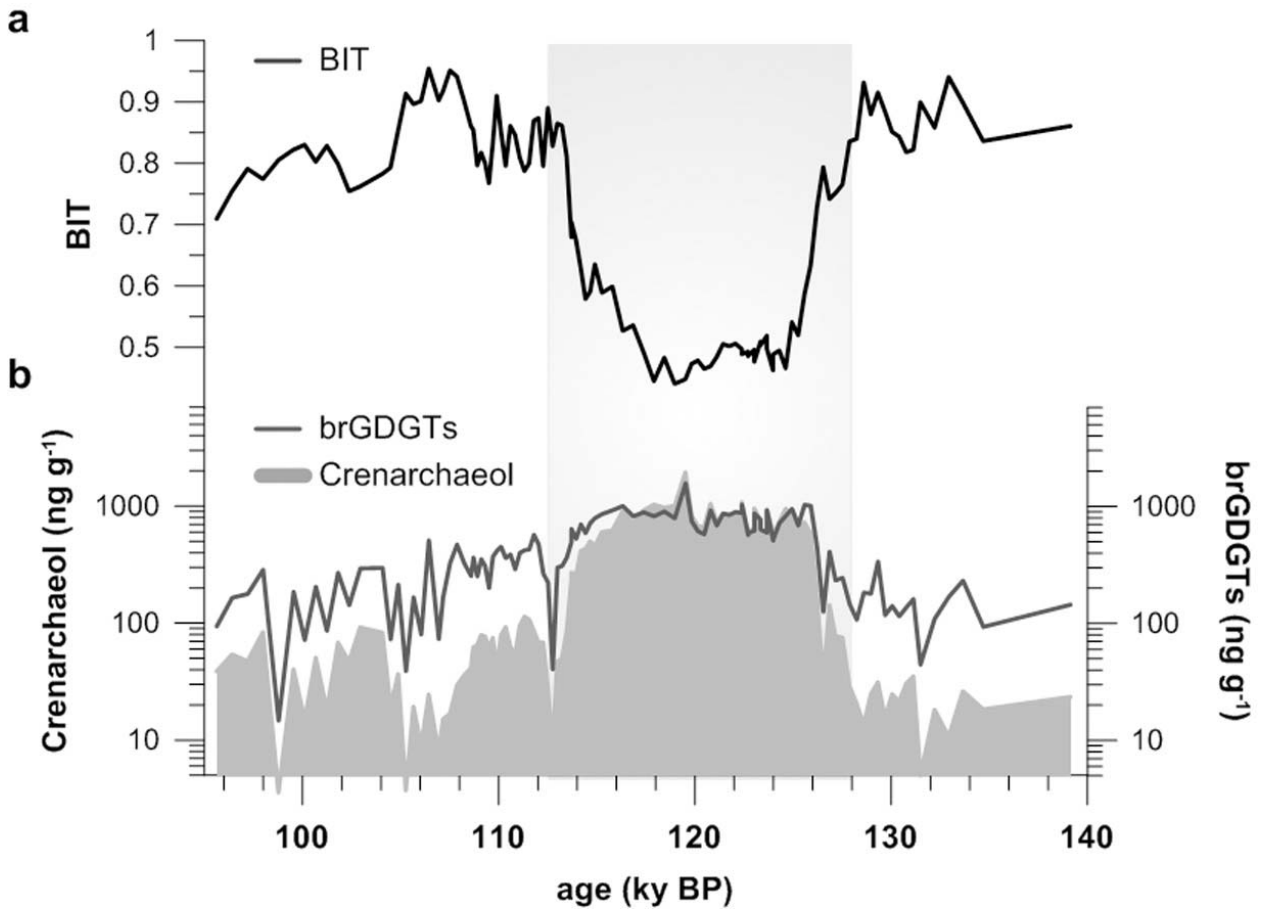

Figure 4. Lake Baikal last interglacial and transitional periods: (a) BIT index and (b) branched GDGTs and crenarchaeol. The shaded area highlights approximately the last interglacial period. 
(a-c) Southern Ocean

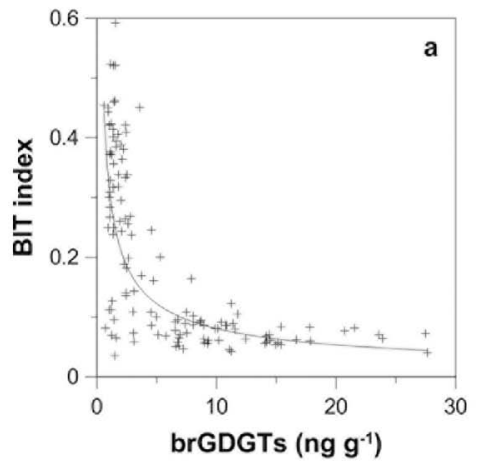

(d-f) Lake Baikal last interglacial

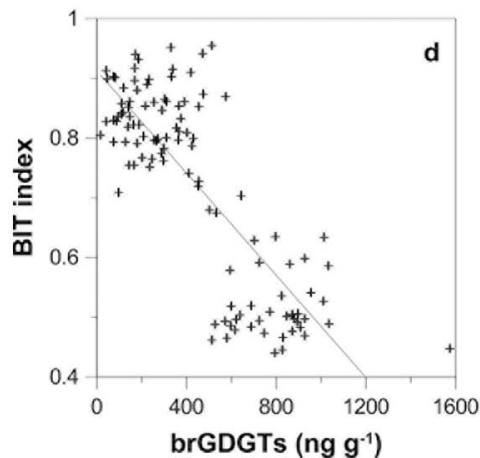

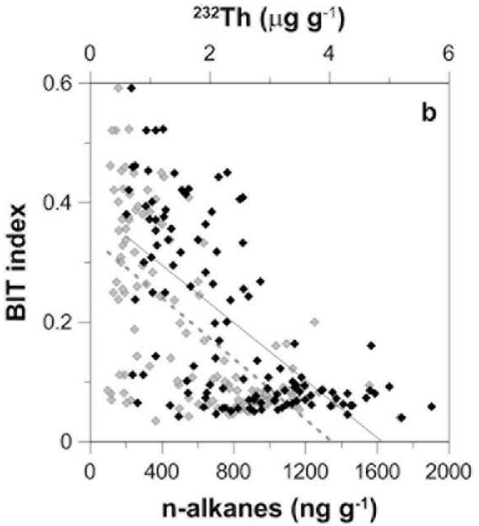

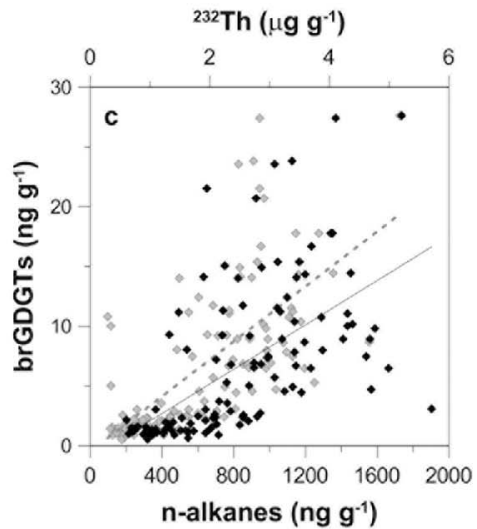

$\mathrm{C}: \mathrm{N}$

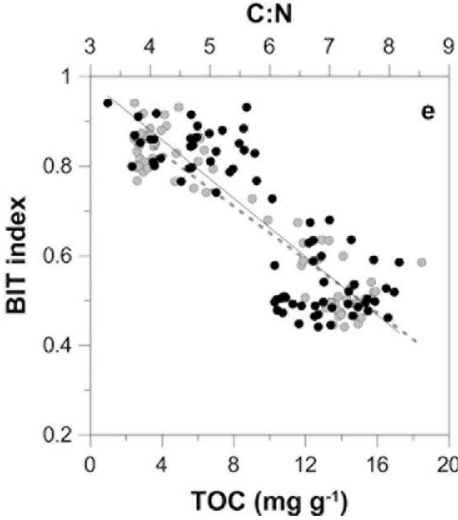

$\mathrm{C}: \mathrm{N}$

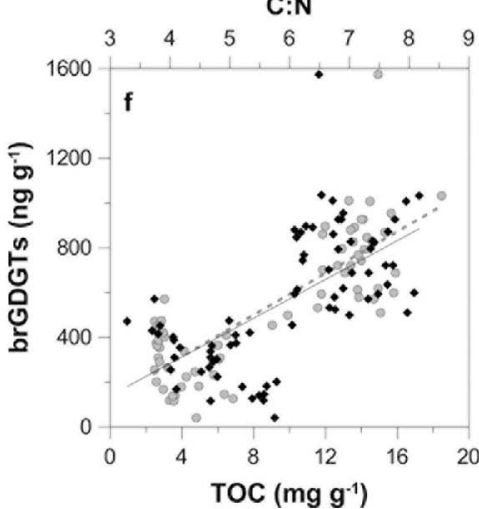

Figure 5. Relationship of branched GDGT concentrations with BIT index as well as both with other potential terrestrial matter input proxies, respectively: $(\mathrm{a}-\mathrm{c})$ in the Southern Ocean record (see Figure 2) [cf. Martínez-Garcia et al., 2009] and (d-f) in the record of Lake Baikal Interglacial and transitional periods (see Figure 4) [cf. Fietz et al., 2007]. In Figures 5a and 5d, BIT is negatively related to branched GDGTs (crosses, $\mathrm{r}^{2}=0.58$ and 0.65 , respectively). In Figure $5 \mathrm{~b}, \mathrm{BIT}$ is negatively related to $\mathrm{n}$-alkanes (grey diamonds, $r^{2}=0.42$ ) and ${ }^{232}$ Thorium (black diamonds, $r^{2}=0.41$ ). In Figure $5 \mathrm{c}$, branched GDGTs are positively related to $\mathrm{n}$-alkanes (grey diamonds, $r^{2}=0.5$ ) and ${ }^{232}$ Thorium (black diamonds, $r^{2}=0.35$ ). In Figure 5e, BIT is negatively related to total organic carbon (TOC, which includes both aquatic and terrestrial sources; grey circles, $r^{2}=0.87$ ) and the $\mathrm{C}: \mathrm{N}$ ratio (black circles, $r^{2}=0.69$ ). In Figure $5 \mathrm{f}$, branched GDGTs are positively related to TOC (grey circles, $r^{2}=0.65$ ) and the $\mathrm{C}: \mathrm{N}$ ratio (black circles, $r^{2}=0.4$ ).

or mixotrophic [e.g., Ingalls et al., 2006] and depend on phytoplankton-derived carbon, or if they are chemoautotrophic nitrifiers [e.g., Herndl et al., 2005; Könneke et al., 2005] through the increase in the supply of ammonium produced by phytoplankton degradation.

\section{Conclusions}

[21] The BIT index was defined as the relative abundance of terrestrially derived branched GDGTs versus crenarchaeol, therefore, its variability is driven by changes in both components [Hopmans et al., 2004]. In agreement with earlier studies [Herfort et al., 2006; Walsh et al., 2008; Belicka and Harvey, 2009], our results illustrate further that the BIT index may be controlled largely by the aquatic GDGT abundance rather than by inputs of terrestrial GDGTs. A change in the BIT therefore does not necessarily reflect a change in the flux of terrestrial carbon. The quantification of branched GDGT concentrations or fluxes might give a better estimate of the soil-derived organic matter input, as long as aquatic in situ production of the branched GDGTs can be excluded at the study site.

[22] Acknowledgments. Marina Escala and Vicky Peck are thanked for providing part of the data, and Nuria Moraleda is thanked for technical assistance. We thank the two anonymous reviewers for their constructive comments. S.F. thanks the Deutsche Forschungsgemeinschaft (DFG) for Postdoctoral Fellowship FI 1466/1-1. Support for this work was provided by the Spanish Ministry of Science and Innovation (MICINN) as research funds (POL2006-02990, CGL2008-03288-E, CGL2010-15000), a Formación del Profesorado Universitario (FPU) studentship to A.M.G. and G.R. (AP2004-7151 and AP2008-801, respectively), Juan de la Cierva fellowships to S.F. and C.H., and a European Commission Marie Curie-IOF (235626) to A.R.M.

\section{References}

Belicka, L. L., and H. R. Harvey (2009), The sequestration of terrestrial organic carbon in Arctic Ocean sediments: A comparison of methods and implications for regional carbon budgets, Geochim. Cosmochim. Acta, 73, 6231-6248, doi:10.1016/j.gca.2009.07.020.

Birks, H. H., and H. J. B. Birks (2006), Multi-proxy studies in palaeolimnology, Veg. Hist. Archaeobot., 15, 235-251, doi:10.1007/s00334006-0066-6. 
Brochier-Armanet, C., B. Boussau, S. Gribaldo, and P. Forterre (2008), Mesophilic Crenarchaeota: Proposal for a third archaeal phylum, the Thaumarchaeota, Nat. Rev. Microbiol., 6, 245-252, doi:10.1038/ nrmicro1852.

de la Torre, J. R., C. B. Walker, A. E. Ingalls, M. Könneke, and D. A. Stahl (2008), Cultivation of a thermophilic ammonia oxidizing archaeon synthesizing crenarchaeol, Environ. Microbiol., 10, 810-818, doi:10.1111/ j.1462-2920.2007.01506.x.

Démory, F., N. R. Nowaczyk, A. Witt, and H. Oberhänsli (2005), Highresolution magnetostratigraphy of late quaternary sediments from Lake Baikal, Siberia: Timing of intracontinental paleoclimatic responses, Global Planet. Change, 46, 167-186, doi:10.1016/j.gloplacha.2004.09.016.

Donders, T. H., J. W. H. Weijers, D. K. Munsterman, M. L. Kloosterboer-van Hoeve, L. K. Buckles, R. D. Pancost, S. Schouten, J. S. Sinninghe Damsté, and H. Brinkhuis (2009), Strong climate coupling of terrestrial and marine environments in the Miocene of northwest Europe, Earth Planet. Sci. Lett., 281, 215-225, doi:10.1016/j.eps1.2009.02.034

Escala, M. (2009), Application of tetraether membrane lipids as proxies for continental climate reconstruction in Iberian and Siberian lakes, Ph.D. thesis, Univ. Autònoma de Barcelona, Spain.

Escala, M., A. Rosell-Melé, and P. Masqué (2007), Rapid screening of glycerol dialkyl glycerol tetraethers in continental Eurasia samples using HPLC/APCI-ion trap mass spectrometry, Org. Geochem., 38, 161-164, doi:10.1016/j.orggeochem.2006.08.013.

Escala, M., S. Fietz, G. Rueda, and A. Rossell-Melé (2009), Analytical considerations for the use of the paleothermometer Tetraether Index ${ }_{86}$ and the Branched vs Isoprenoid Tetraether Index regarding the choice of cleanup and instrumental conditions, Anal. Chem., 81, 2701-2707, doi: $10.1021 / \mathrm{ac} 8027678$.

Fietz, S., A. Nicklisch, and H. Oberhaensli (2007), Phytoplankton response to climate changes in Lake Baikal during the Holocene and Kazantsevo Interglacials assessed from sedimentary pigments, J. Paleolimnol., 37, 177-203, doi:10.1007/s10933-006-9012-y.

Fietz, S., A. Martínez-Garcia, G. Rueda, V. L. Peck, C. Huguet, M. Escala, and A. Rosell-Melé (2011), Crenarchaea and phytoplankton coupling in sedimentary archives: Common trigger or metabolic dependence? Limnol. Oceanogr., 56, 1907-1916, doi:10.4319/lo.2011.56.5.1907.

Gordon, E. S., and M. Goñi (2003), Sources and distribution of terrigenous organic matter delivered by the Atchafalaya River to sediments in the northern Gulf of Mexico, Geochim. Cosmochim. Acta, 67, 2359-2375, doi:10.1016/S0016-7037(02)01412-6.

Hebbeln, D. (2000), Flux of ice-rafted detritus from sea ice in the Fram Strait, Deep Sea Res., Part II, 47, 1773-1790, doi:10.1016/S0967-0645 (00)00006-0.

Hedges, J. I., and J. M. Oades (1997), Comparative organic geochemistries of soils and marine sediments, Org. Geochem., 27, 319-361, doi:10.1016/ S0146-6380(97)00056-9.

Heim, B., S. Fietz, H. Oberhaensli, and H. Kaufmann (2005), Variation in Lake Baikal's phytoplankton distribution and fluvial input assessed by SeaWiFS satellite data, Global Planet. Change, 46, 9-27, doi:10.1016/ j.gloplacha.2004.11.011.

Herfort, L., S. Schouten, J. P. Boon, M. Woltering, M. Baas, J. W. H. Weijers, and J. S. Sinninghe Damsté (2006), Characterization of transport and deposition of terrestrial organic matter in the southern North Sea using the BIT index, Limnol. Oceanogr., 51, 2196-2205, doi:10.4319/lo.2006. 51.5.2196

Herndl, G. J., T. Reinthaler, E. Teira, H. van Aken, C. Veth, A. Pernthaler, and J. Pernthaler (2005), Contribution of Archaea to total prokaryotic production in the deep Atlantic Ocean, Appl. Environ. Microbiol., 71, 2303-2309, doi:10.1128/AEM.71.5.2303-2309.2005.

Hopmans, E. C., J. W. H. Weijers, E. Schefuß, L. Herfort, J. S. Sinninghe Damsté, and S. Schouten (2004), A novel proxy for terrestrial organic matter in sediments based on branched and isoprenoid tetraehter lipids, Earth Planet. Sci. Lett., 224, 107-116, doi:10.1016/j.eps1.2004.05.012.

Huguet, C., R. H. Smittenberg, W. Boer, J. S. Sinninghe Damsté, and S. Schouten (2007), Twentieth century proxy records of temperature and soil organic matter input in the Drammensfjord, southern Norway, Org. Geochem., 38, 1838-1849, doi:10.1016/j.orggeochem.2007.06.015.

Huguet, C., G. J. de Lange, J. J. Middelburg, J. S. Sinninghe Damsté, and S. Schouten (2008), Selective preservation of soil organic matter in oxidized marine sediments (Madeira Abyssal Plain), Geochim. Cosmochim. Acta, 72, 6061-6068, doi:10.1016/j.gca.2008.09.021.

Huguet, C., B. Martrat, J. O. Grimalt, J. S. Sinninghe Damsté, and S. Schouten (2011), Coherent millennial scale patterns in $\mathrm{U}_{37}^{\mathrm{K}^{\prime}}$ and $\mathrm{TEX}_{86}^{\mathrm{H}}$ temperature records during the penultimate interglacial-to-glacial cycle in the western Mediterranean, Paleoceanography, 26, PA2218, doi:10.1029/ 2010PA002048.

Ingalls, A. E., S. R. Shah, R. L. Hansman, L. I. Aluwihare, G. M. Santos, E. R. M. Druffel, and A. Pearson (2006), Quantifying archaeal community autotrophy in the mesopelagic ocean using natural radiocarbon, Proc. Natl. Acad. Sci. U. S. A., 103, 6442-6447, doi:10.1073/pnas.0510157103.

Kim, J.-H., W. Ludwig, S. Schouten, P. Kerhervé, L. Herfort, J. Bonnin, and J. S. Sinninghe Damsté (2007), Impact of flood events on the transport of terrestrial organic matter to the ocean: A study of the Têt River (SW France) using the BIT index, Org. Geochem., 38, 1593-1606, doi:10.1016/j.orggeochem.2007.06.010.

Kim, J.-H., R. Buscail, F. Bourrin, A. Palanques, J. S. Sinninghe Damsté, J. Bonnin, and S. Schouten (2009), Transport and depositional process of soil organic matter during wet and dry storms on the Têt inner shelf (NW Mediterranean), Palaeogeogr. Palaeoclimatol. Palaeoecol., 273, 228-238, doi:10.1016/j.palaeo.2008.04.019.

Könneke, M., A. E. Bernhard, J. R. de la Torre, C. B. Walker, J. B. Waterbury, and D. A. Stahl (2005), Isolation of an autotrophic ammonia-oxidizing marine archaeon, Nature, 437, 543-546, doi:10.1038/nature03911.

Kozhova, O. M., and L. R. Izmest'eva (1998), Lake Baikal, Evolution and Biodiversity, Backhuys, Leiden, Netherlands.

Leininger, S., T. Urich, M. Schloter, L. Schwark, J. Qi, G. Nicol, J. Prosser, S. Schuster, and C. Schleper (2006), Archaea predominate among ammonia-oxidizing prokaryotes in soils, Nature, 442, 806-809, doi:10.1038/nature04983.

Mackay, A. W. (2007), The paleoclimatology of Lake Baikal: A diatom synthesis and prospectus, Earth Sci. Rev., 82, 181-215, doi:10.1016/ j.earscirev.2007.03.002.

Martínez-Garcia, A., A. Rosell-Melé, W. Geibert, R. Gersonde, P. Masqué, V. Gaspari, and C. Barbante (2009), Links between iron supply, marine productivity, sea surface temperature and $\mathrm{CO}$ over the last $1.1 \mathrm{Ma}$, Paleoceanography, 24, PA1207, doi:10.1029/2008PA001657.

Martínez-Garcia, A., A. Rosell-Melé, S. L. Jaccard, W. Geibert, D. M. Sigman, and G. H. Haug (2011), Southern Ocean dust-climate coupling during the past 4 million years, Nature, 476, 312-315, doi:10.1038/ nature 10310 .

Martrat, B., J. O. Grimalt, C. Lopez-Martinez, I. Cacho, F. J. Sierro, J. A. Flores, R. Zahn, M. Canals, J. H. Curtis, and D. A. Hodell (2004), Abrupt temperature changes in the western Mediterranean over the past 250,000 years, Science, 306, 1762-1765, doi:10.1126/science.1101706.

Ménot, G., E. Bard, F. Rostek, J. W. H. Weijers, E. C. Hopmans, S. Schouten, and J. S. Sinninghe Damsté (2006), Early reactivation of European rivers during the last deglaciation, Science, 313, 1623-1625, doi:10.1126/science. 1130511 .

Meyers, P. A. (1997), Organic geochemical proxies of paleoceanographic, paleolimnologic, and paleoclimatic processes, Org. Geochem., 27, 213-250, doi:10.1016/S0146-6380(97)00049-1.

Ouverney, C. C., and J. A. Fuhrman (2000), Marine planktonic Archaea take up amino acids, Appl. Environ. Microbiol., 66, 4829-4833.

Pancost, R. D., and C. S. Boot (2004), The palaeoclimatic utility of terrestrial biomarkers in marine sediments, Mar. Chem., 92, 239-261, doi:10.1016/j.marchem.2004.06.029.

Pearson, A., Z. Huang, A. E. Ingalls, C. S. Romanek, J. Wiegel, K. H. R. Freeman, H. Smittenberg, and C. L. Zhang (2004), Nonmarine crenarchaeol in Nevada hot springs, Appl. Environ. Microbiol., 70, 5229-5237, doi:10.1128/AEM.70.9.5229-5237.2004.

Peck, V. L., I. R. Hall, R. Zahn, H. Elderfield, F. Grousset, S. R. Hemming, and J. D. Scourse (2006), High resolution evidence for linkages between NW European ice sheet instability and Atlantic meridional overturning circulation, Earth Planet. Sci. Lett., 243, 476-488, doi:10.1016/j.eps1. 2005.12.023.

Peterse, F., J.-H. Kim, S. Schouten, D. K. Kristensen, N. Koc, and J. S. Sinninghe Damsté (2009), Constraints on the application of the MBT/ CBT palaeothermometer at high latitude environments (Svalbard, Norway), Org. Geochem., 40, 692-699, doi:10.1016/j.orggeochem.2009.03.004.

Pitcher, A., S. Schouten, and J. S. Sinninghe Damsté (2009), In situ production of crenarchaeol in two California hot springs, Appl. Environ. Microbiol., 75, 4443-4451, doi:10.1128/AEM.02591-08.

Réthoré, G., T. Montier, T. Le Gall, P. Delépine, S. Cammas-Marion, L. Lemiègre, P. Lehn, and T. Benvegnu (2007), Archaeosomes based on synthetic tetraether-like lipids as novel versatile gene delivery systems, Chem. Commun., 28, 2054-2056, doi:10.1039/b618568a.

Schmid, M., N. M. Budnev, N. G. Granin, M. Sturm, M. Schurter, and A. Wüest (2008), Lake Baikal deepwater renewal mystery solved, Geophys. Res. Lett., 35, L09605, doi:10.1029/2008GL033223.

Schouten, S., C. Huguet, E. C. Hopmans, M. Kienhuis, and J. S. Sinninghe Damsté (2007), Analytical methodology for $\mathrm{TEX}_{86}$ paleothermometry by high-performance liquid chromatography/atmospheric pressure chemical ionization-mass spectrometry, Anal. Chem., 79, 2940-2944, doi:10.1021/ac062339v

Schouten, S., et al. (2009), An interlaboratory study of $\mathrm{TEX}_{86}$ and BIT analysis using high-performance liquid chromatography-mass spectrometry, Geochem. Geophys. Geosyst., 10, Q03012, doi:10.1029/2008GC002221. 
Sinninghe Damsté, J. S., S. Schouten, E. C. Hopmans, A. C. T. Van Duin, and J. A. J. Geenevasen (2002), Crenarchaeol: The characteristic core glycerol dibiphytanyl glycerol tetraether membrane lipid of cosmopolitan pelagic Crenarchaea, J. Lipid Res., 43, 1641-1651, doi:10.1194/ jlr.M200148-JLR200.

Sinninghe Damsté, J. S., J. Ossebaar, B. Abbas, S. Schouten, and D. Verschuren (2009), Fluxes and distribution of tetraether lipids in an equatorial African lake: Constraints on the application of the TEX $_{86}$ palaeothermometer and BIT index in lacustrine settings, Geochim. Cosmochim. Acta, 73, 4232-4249, doi:10.1016/j.gca.2009.04.022.

Sinninghe Damsté, J. S., W. I. C. Rijpstra, E. C. Hopmans, J. W. H. Weijers, B. U. Foesel, J. Overmann, and S. N. Dedysh (2011), 13,16-Dimethyl octacosanedioic acid (iso-diabolic acid), a common membrane-spanning lipid of Acidobacteria subdivisions 1 and 3, Appl. Environ. Microbiol., 77, 4147-4154, doi:10.1128/AEM.00466-11.

Sluijs, A., et al. (2006), Subtropical Arctic Ocean temperatures during the Palaeocene/Eocene thermal maximum, Nature, 441, 610-613, doi:10.1038/nature04668.

Smith, R., T. S. Bianchi, and C. Savage (2010), A comparison of ligninphenols and branched/isoprenoid tetraethers (BIT index) as indices of terrestrial organic matter in Doubtful Sound, Fiordland, New Zealand, Org. Geochem., 41, 281-290, doi:10.1016/j.orggeochem.2009.10.009.

Spielhagen, R., K. Werner, S. Sorensen, K. Zamelczyk, E. Kandiano, G. Budeus, K. Husum, T. Marchitto, and M. Hald (2011), Enhanced modern heat transfer to the Arctic by Warm Atlantic Water, Science, 331, 450-453, doi:10.1126/science.1197397.

Tierney, J. E., J. M. Russell, H. Eggermont, E. C. Hopmans, D. Verschuren, and J. S. Sinninghe Damsté (2010), Environmental controls on branched tetraether lipid distributions in tropical East African lake sediments, Geochim. Cosmochim. Acta, 74, 4902-4918, doi:10.1016/j.gca. 2010.06.002.
Walsh, E. M., A. E. Ingalls, and R. G. Keil (2008), Sources and transport of terrestrial organic matter in Vancouver Island fjords and the VancouverWashington Margin: A multiproxy approach using d13Corg, lignin phenols, and the ether lipid BIT index, Limnol. Oceanogr., 53, 1054-1063, doi:10.4319/1o.2008.53.3.1054.

Weijers, J. W. H., S. Schouten, E. C. Hopmans, J. A. J. Geenevasen, O. R. P. David, J. M. Coleman, R. D. Pancost, and J. S. Sinninghe Damsté (2006a), Membrane lipids of mesophilic anaerobic bacteria thriving in peats have typical archaeal traits, Environ. Microbiol., 8 , 648-657, doi:10.1111/j.1462-2920.2005.00941.x.

Weijers, J. W. H., S. Schouten, O. Spaargaren, and J. S. Sinninghe Damsté (2006b), Occurrence and distribution of tetraether membrane lipids in soils: Implications for the use of the $\mathrm{TEX}_{86}$ proxy and the BIT index, Org. Geochem., 37, 1680-1693, doi:10.1016/j.orggeochem.2006.07.018. Weijers, J. W. H., S. Schouten, E. Schefuß, R. R. Schneider, and J. S. Sinninghe Damsté (2009a), Disentangling marine, soil and plant organic carbon contributions to continental margin sediments: A multiproxy approach in a 20,000 year sediment record from the Congo deep-sea fan, Geochim. Cosmochim. Acta, 73, 119-132, doi:10.1016/j.gca. 2008.10.016.

Weijers, J. W. H., E. Panoto, J. van Bleijswijk, S. Schouten, M. Balk, A. J. M. Stams, W. I. C. Rijpstra, and J. S. Sinninghe Damsté (2009b), Constraints on the biological source(s) of the orphan, branched tetraether membrane lipids, Geomicrobiol. J., 26, 402-414, doi:10.1080/ 01490450902937293.

S. Fietz, C. Huguet, A. Rosell-Melé, and G. Rueda, Institut de Ciència i Tecnologia Ambientals, Universitat Autònoma de Barcelona, Campus Bellaterra, Barcelona E-08913, Spain. (susanne.fietz@uab.cat)

A. Martínez-Garcia, Geologisches Institut, ETH Zurich, Sonneggstr. 5, CH-8092 Zürich, Switzerland. 